\title{
Secondary School Students' Mental Models Regarding the Space
}

\author{
Sendil Can $^{1} \&$ Meryem Gorecek Baybars ${ }^{1}$ \\ ${ }^{1}$ Faculty of Education, Mugla Sttk1 Kocman University, Mugla, Turkey \\ Correspondence: Meryem Gorecek Baybars, Faculty of Education, Mugla Sitkı Kocman University, Mugla, \\ Turkey.
}

Received: April 3, 2018

doi:10.5539/jel.v7n4p122

\author{
Accepted: May 2, $2018 \quad$ Online Published: May 15, 2018 \\ URL: https://doi.org/10.5539/jel.v7n4p122
}

\begin{abstract}
This study was carried out to reveal the mental models of the secondary school students from different grade levels regarding the concept of space. At the same time, within the context of the study, it was aimed to determine the factors playing a role in the construction of their concepts of space. The study employed the special case study design, one of the descriptive methods. The study was conducted in the spring term of the 2016-2017 school year and the sampling of the study is comprised of the students attending a private secondary school in a city located in the western region of Turkey. In the study, a data collection tool including four open-ended questions developed by the researchers to determine the students' mental models of the "space" was used. The collected data were analyzed by using descriptive statistical techniques. The findings of the study have revealed that the students mostly associate the concept of the space with the concepts of emptiness (53 students), infinity ( 50 students), planet (48 students) and star (28 students). These findings are also supported by the students' drawings and the Celestial Bodies Mental Model was found to be the model most frequently used by the students.
\end{abstract}

Keywords: mental models, space, secondary school students

\section{Introduction}

\subsection{Introduce the Problem}

Science and art have made rapid progress, from man's existence up to now. Astronomy, which has a powerful appeal to human intelligence and imagination (Spiliotopoulou-Papantoniou, 2007), and celestial occurrences that are the main theme of astronomy have been regarded as miracles by people and have become a source of inspiration for scientific developments. The word astronomy is derived from the words "astron" and "nomos" in the ancient Greek, meaning "inter-stellar" or "stellar science". Astronomy is the ancestor of basic sciences (Trumper, 2006) and has played a role in the development of other basic sciences such as physics, chemistry, biology and mathematics. Astronomy did not receive enough attention from the establishment of the Ottoman Empire to the reign of Sultan Mehmet the Conqueror; yet, in the era of Sultan Mehmet, particularly with the invitation of Ali Kuscu to Istanbul, it lived its heyday (Unat, 2010). The first contact with modern astronomy dates back to the middle of the 17th century, and after the Tanzimat reform era, information on astronomy taught in some schools seems to have made up the content of an independent course up to 1937 (Tunca, 2002). In later years, astronomy course was taught as an elective course. Especially the launch of the "Sputnik" spacecraft by the Russians can be considered a milestone. Countries such as the USA, Canada, France, Australia, Italy, and the UK have started to reconstruct their curriculums by incorporating astronomy into all their instructional programs. In Turkey, astronomy, which has found wider place in the curriculums especially in recent years, has started to be taught within the units of "The Sun, The World and The Moon" in the first grade, "The Solar System and Eclipses" in the second grade, "The Solar System and Beyond" in the third grade and "Seasons and Climate" in the fourth grade of elementary education as a result of the renewal of the science curriculum in 2017.

Especially in recent years, astronomy and its related concepts have been studied by many researchers and important studies have been carried out to contribute to this field. When the relevant literature is reviewed, it is seen that there are some studies conducted to determine attitudes towards astronomy (Bektasl1, 2013; Ucar \& Demircioglu, 2011; Wittman, 2009), some studies focus on the basic concepts of astronomy (Bulbul, Iyibil, \& Sahin, 2013; Joolingen, Aukes, Gijlers, \& Bollen, 2014; Kurnaz, 2012; Turk, 2010; Ozturk, 2011; Turk, Alemdar, \& Kalkan, 2012), some others aim to elicit individuals' mental models (Celik \& Tekbıyık, 2016; Liu, 
2003; Mustu, 2016; Panagiotaki, Nobes, \& Potton, 2008; Samarapungavan, Vosniadou, \& Brewer, 1996; Straatemeier, Van der Mass, \& Jansen, 2008; Taylor, Baker, \& Jones, 2003; Vosniadou \& Brewer, 1992; Vosniadou, Skopeliti, \& Ikospentaki, 2004).

Mental models; according to Hestenes (2006), are specific structures in the individual's mind and according to Ornek (2008), they can be defined as psychological representations of real or imaginary situations. Mental models are mental presentations used to make the physical world logical (Coll \& Tregaust, 2003). According to Franco \& Colinvaux (2000), the characteristics of mental models can be grouped under certain headings. Mental models are productive because they lead to the identification and production of new information. Mental models contain implicit information because people using mental models may not be aware that they are using these models. Mental models are synthetic and limited to the world view of individuals (cited in Chia-yu, 2007).

Coll \& Treagust (2003) addressed mental models in two groups, physical and conceptual mental models. An example of physical mental models is a person's visualization of organ images in the human body in his/her mind and the atom model or space in the mind of a person can be given as an example of the conceptual mental models. The mental models that individuals use to make sense of the physical world and to interpret everyday events they encounter (Yurumzoglu \& Cokelez, 2010) can be an important source of new information production and theory building (Vosniadou, 2002). According to Vosniadou \& Brewer (1994), mental models that provide data on beliefs and previously acquired information also affect the processes of information acquisition and can also be limited by information previously acquired. Mental models used by the individual to understand, explain and predict the behaviors of the real world are influenced by the individual's existing models and are structured on the basis of the individual's own contexts (Kurnaz \& Degirmenci, 2012). Mental models that are important in understanding students' misconceptions or the resistance of alternative concepts to change and for their academic achievement (Unal \& Ergin, 2006) are also effective in explaining complex views that include scientific principles and theories (Rapp, 2005).

When studies in the literature are reviewed, it is seen that different methods have been used to elicit mental models (Ayvacı, Bebek, Atik, Keles, \& Ozdemir, 2016; Boulter \& Buckley, 2000; Coll \& Tregaust, 2003; Celik \& Tekbıyık, 2016; De Posada, 1997; Gorecek Baybars, 2017; Jabot \& Henry, 2007; Kibble, 1999; Yurumezoglu \& Cokelez, 2010; Williamson \& Abraham, 1995). These methods can be open-ended questions, multiple-choice questions and interviews including classroom observations (Chia-Yu, 2007). In addition, asking students to illustrate their explanations through drawings can also make mental models clearer because student drawings are representations of mental models. Therefore, asking students to illustrate their explanations through drawings makes their mental models more evident (White \& Gunstone, 1992). Another benefit of drawings is that they make the concepts that exist in the individual's mind and the dimensions that cannot be revealed by examination techniques visible (Atasoy, 2004).

When studies on astronomy and mental models in the teaching process are examined, it is seen that there is a paucity of research on the concept of "space". In the literature, only two studies directly addressing the concept of "space" have been detected (Karamustafaoglu \& Akturk, 2016; Celik \& Tekbiyık, 2016). Karamustafaoglu \& Akturk (2016) attempted to determine the elementary school 3rd and 4th graders' metaphors about the concept of "space" and Celik \& Tekbiyık (2016) aimed to elicit the elementary school 2nd graders' mental models and images about the concepts of "World and Space". In the literature, no study looking at the secondary school students in terms of their mental models of the space has been found. Thus, the current study is believed to help fill this void. Moreover, as the current study aimed to elicit secondary school students' mental models regarding the concept of space, it can provide important insights for researchers and practitioners in this field and the findings of the study can contribute to the better organization of instructional activities.

\section{Method}

\subsection{Research Goal}

The purpose of the current study is to determine the secondary school students' mental models regarding the concept of "space" and to elicit the factors affecting the construction of their concepts of "space".

\subsection{Sample and Data Collection}

The current study employed the special case study design, one of the descriptive methods. The descriptive method is preferred by many researchers as the research can be conducted without distorting the natural conditions and making any changes in the environment under investigation when this method is employed (Cepni, 2005). This study is descriptive in nature because it aims to determine students' mental models regarding the concept of "space" without distorting the natural conditions. The descriptive method is effective in providing 
a detailed description and explanation of the case under investigation and evaluating it in line with its standards (Cepni, 2010). The special case study design enables the researcher to collect detailed information in a short time in line with the purpose of the study (Yin, 2003; Cepni, 2010). The most important advantage of the special case study design is allowing the researcher to get concentrated on the subject or the case. Though there is no certain rule to determine the sample size in qualitative research, it is determined depending on the purpose of the research, what is desired to be known, the time available and what can be done with resources at hand (Patton, 2014). In this respect, the current study was conducted in the spring term of the 2016-2017 school year and the sample is comprised of the secondary school students of a private school in a city located in the western part of Turkey. A total of 144 secondary school students participated in the study. Of these participating students, 42 are first grade students, 38 are second grade students, 31 are third grade students and 33 are fourth grade students. Moreover, 71 of these 144 students are girls and 73 are boys. The students are coded with numbers (S1, S2, $\mathrm{S} 3, \ldots \ldots \ldots . . . \mathrm{S} 144)$. In this coding, $\mathrm{S}$ stands for the student and numbers refer to their order. Some demographics of the students are given in Table 1 and Table 2.

Table 1. Distribution of students across the grade levels

\begin{tabular}{lll}
\hline Grade Level & f & $\%$ \\
\hline Secondary School $1^{\text {st }}$ grade & 42 & 29.16 \\
Secondary School 2 $^{\text {nd }}$ grade & 38 & 26.38 \\
Secondary School 3 $^{\text {rd }}$ grade & 31 & 21.52 \\
Secondary School ${ }^{\text {th }}$ grade & 33 & 22.91 \\
\hline Total & 144 & 100 \\
\hline
\end{tabular}

Table 2. Gender-based distribution of students

\begin{tabular}{lll}
\hline Gender & $\mathrm{f}$ & $\%$ \\
\hline Girl & 71 & 49.30 \\
Boy & 73 & 50.69 \\
\hline Total & 144 & 100 \\
\hline
\end{tabular}

In the study, a data collection tool consisting of 4 open-ended questions developed by the researchers was employed to determine the students' mental models regarding the concept of "space". In order to establish the content validity of the data collection tool, opinions of two science education experts and a physics education expert were sought. In line with the feedbacks taken from the experts, the required corrections were made on the questions and they were constructed for the students to understand. In order to determine the reliability of the test, the responses of 20 students were coded by the two researchers and then their consistency coefficient was calculated. This coefficient was found to be $92 \%$. The questions in the data collection tool are as follows:

1) What does the term "Space" mean for you? Please, explain briefly.

2) Please draw the picture that occurs in your mind when you hear the word "Space".

3) Where have you received the information that you have about the "Space"?

4) Do you have any points that you wonder about in relation the "Space"? If yes, what are they? What would you like to learn about the "Space?

Considering that the participation in the study should be on a volunteer basis, during the data collection process the students were explained that the study had a scientific purpose, the results would not be used to asses students and it was not important whether the drawings are nice or ugly.

\subsection{Analyzing of Data}

In the analysis of the collected data, the descriptive analysis method was used. In line with the purpose of the study and the questions in the data collection tool, the collected data were analyzed, themes and codes were determined and percentage and frequency values are presented in tables.

\section{Results}

Findings obtained for the first question:

The findings obtained when the students' responses to the question "What does the term "Space" mean for you? Please, explain briefly?" were analyzed are presented in Table 3. 
Table 3. The concepts used by the students to explain the term "Space"

\begin{tabular}{|c|c|c|c|c|c|c|c|c|c|c|}
\hline \multirow[b]{2}{*}{ Concepts } & \multicolumn{2}{|c|}{$1^{\text {st }}$ grade } & \multicolumn{2}{|c|}{$2^{\text {nd }}$ grade } & \multicolumn{2}{|c|}{$3^{\text {rd }}$ grade } & \multicolumn{2}{|c|}{$4^{\text {th }}$ grade } & \multicolumn{2}{|c|}{ Total } \\
\hline & $\mathrm{f}$ & $\%$ & $\mathrm{f}$ & $\%$ & $\mathrm{f}$ & $\%$ & $\mathrm{f}$ & $\%$ & $\mathrm{f}$ & $\%$ \\
\hline Emptiness & 17 & 40.47 & 16 & 42.10 & 11 & 35.48 & 9 & 27.27 & 53 & 36.80 \\
\hline Infinity & 11 & 26.19 & 12 & 31.57 & 16 & 51.61 & 11 & 33.33 & 50 & 34.72 \\
\hline Planet & 23 & 54.76 & 14 & 36.84 & 4 & 12.90 & 7 & 21.21 & 48 & 33.33 \\
\hline Star & 12 & 28.57 & 10 & 26.31 & 2 & 6.45 & 4 & 12.12 & 28 & 19.44 \\
\hline Astronaut & 12 & 28.57 & 3 & 7.89 & 1 & 3.22 & - & - & 16 & 11.11 \\
\hline Universe & 4 & 9.52 & 2 & 5.26 & 4 & 12.90 & 4 & 12.12 & 14 & 9.72 \\
\hline Sun & 6 & 14.28 & 5 & 13.15 & - & - & - & - & 11 & 7.63 \\
\hline Alien & 7 & 16.66 & 2 & 5.26 & - & - & 1 & 3.03 & 10 & 6.94 \\
\hline Darkness & 1 & 2.38 & 6 & 15.78 & 1 & 3.22 & 1 & 3.03 & 9 & 6.25 \\
\hline Galaxy & 5 & 11.90 & 1 & 2.63 & - & - & 2 & 6.06 & 8 & 5.55 \\
\hline Mystery & 4 & 9.52 & 2 & 5.26 & 1 & 3.22 & 1 & 3.03 & 8 & 5.55 \\
\hline Black hole & 4 & 9.52 & 4 & 10.52 & - & - & - & - & 8 & 5.55 \\
\hline Black & 5 & 11.90 & - & - & - & - & - & - & 5 & 3.47 \\
\hline Space craft & 3 & 7.14 & 2 & 5.26 & - & - & - & - & 5 & 3.47 \\
\hline World & 4 & 9.52 & - & - & - & - & - & - & 4 & 2.77 \\
\hline Moon & 3 & 7.14 & - & - & - & - & - & - & 3 & 2.08 \\
\hline $\begin{array}{l}\text { Environment } \\
\text { without air }\end{array}$ & 3 & 7.14 & - & - & - & - & - & - & 3 & 2.08 \\
\hline $\begin{array}{l}\text { Environment } \\
\text { without } \\
\text { gravity }\end{array}$ & 2 & 4.76 & 1 & 2.63 & - & - & - & - & 3 & 2.08 \\
\hline Alien & - & - & 2 & 5.26 & - & - & 1 & 3.03 & 3 & 2.08 \\
\hline NASA & 2 & 4.76 & - & - & - & - & - & - & 2 & 1.38 \\
\hline Scientist & 2 & 4.76 & - & - & - & - & - & - & 2 & 1.38 \\
\hline Curiosity & 1 & 2.38 & - & - & - & - & - & - & 1 & 0.69 \\
\hline Meteor & 1 & 2.38 & - & - & - & - & - & - & 1 & 0.69 \\
\hline
\end{tabular}

When Table 3 is examined, it is seen that while the secondary school first grade students most use the concepts such as planet, emptiness, star, astronaut and infinity to explain the term "Space", they use the concepts such as curiosity and meteor the least. While the secondary school second grade students most use the concepts such as emptiness, planet, star and infinity to explain it, they use the concepts of galaxy and the environment without gravity the least. In Table 3, it is also seen that while the secondary school third grade students most use the concepts of infinity and emptiness, they use the concepts such as astronaut, mystery and darkness the least. In Table 3, it is also seen that the secondary school fourth grade students most use the concepts of infinity, planet and emptiness, they use the concepts of alien, darkness and mystery the least. Moreover, while explaining the term "space", the secondary school first grade students used 22 concepts, the secondary school second grade students used 15 concepts, the secondary school third grade students used 8 concepts and the secondary school fourth grade students used 10 concepts. The common concepts used by the secondary school students are "planet, emptiness, infinity, star, mystery, universe, darkness" and the concepts only used by the first grade students are "black, moon, environment without air, NASA, scientist, meteor, curiosity".

Findings obtained for the second question:

The findings obtained from the analysis of the secondary school students' responses to the question "Please draw the picture that occurs in your mind when you hear the word "Space" are presented in Table 4. In the drawings of the students, 6 different mental models were detected. These models are "space exploration models, star model, alien model, celestial bodies model, solar system model, darkness model". While the celestial bodies model was the most commonly used one, space exploration models, solar system model and start model were used less frequently. The least frequently used models were the alien model and darkness model. 
Table 4. Findings obtained from the analysis of the students' responses to the question "Please draw the picture that occurs in your mind when you hear the word "Space"

\begin{tabular}{|c|c|c|c|c|c|c|c|c|c|c|}
\hline \multirow[b]{2}{*}{ Mental models } & \multicolumn{2}{|c|}{$1^{\text {st }}$ grade } & \multicolumn{2}{|c|}{$2^{\text {nd }}$ grade } & \multicolumn{2}{|c|}{$3^{\text {rd }}$ grade } & \multicolumn{2}{|c|}{$4^{\text {th }}$ grade } & \multicolumn{2}{|c|}{ Total } \\
\hline & $\mathrm{f}$ & $\%$ & $\mathrm{f}$ & $\%$ & $\mathrm{f}$ & $\%$ & $\mathrm{f}$ & $\%$ & $\mathrm{f}$ & $\%$ \\
\hline $\begin{array}{l}\text { Celestial bodies } \\
\text { model }\end{array}$ & 21 & 50 & 17 & 44.7 & 13 & 41.93 & 18 & 54.54 & 69 & 47.91 \\
\hline $\begin{array}{l}\text { Space } \\
\text { exploration } \\
\text { model }\end{array}$ & 12 & 28.6 & 9 & 23.7 & - & - & 1 & 3.03 & 22 & 15.27 \\
\hline $\begin{array}{l}\text { Solar } \\
\text { model }\end{array}$ & 2 & 4.8 & 2 & 5.3 & 9 & 29.03 & 9 & 27.27 & 22 & 15.27 \\
\hline Star model & 4 & 9.5 & 7 & 18.4 & 6 & 19.35 & 2 & 6.06 & 19 & 13.19 \\
\hline Alien model & 3 & 7.1 & 2 & 5.3 & 2 & 6.45 & 2 & 6.06 & 9 & 6.25 \\
\hline Darkness model & - & - & 1 & 2.6 & 1 & 3.22 & 1 & 3.03 & 3 & 2.083 \\
\hline Total & 42 & 100 & 38 & 100 & 31 & 100 & 33 & 100 & 144 & 100 \\
\hline
\end{tabular}

When Table 4 is examined, it is seen that 69 students of the 144 students have the celestial bodies mental model. Among the drawings included in this category are there celestial bodies such as sun, world, moon, planet and meteor. The most remarkable finding here is the inclusion of the concept of world in all the drawings. The students, in their drawings, drew the celestial bodies in emptiness or in a wavy structure. Moreover, it was also detected that the students did not pay attention to dimensions while producing their drawings. Sample drawings for the celestial bodies mental model are presented below.

The drawing by S2:
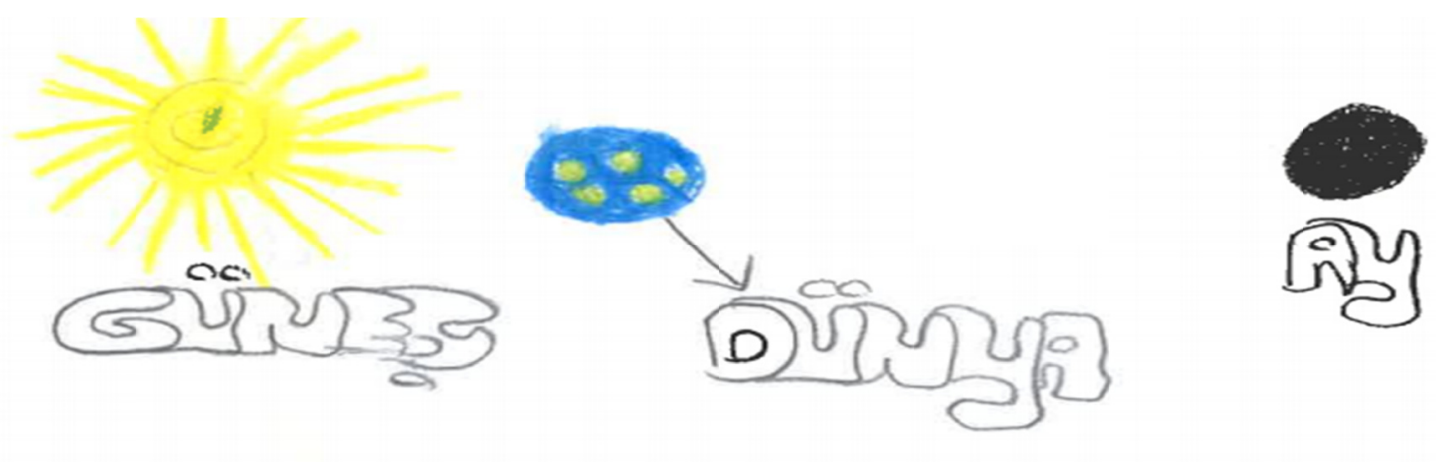

The drawing by S23:
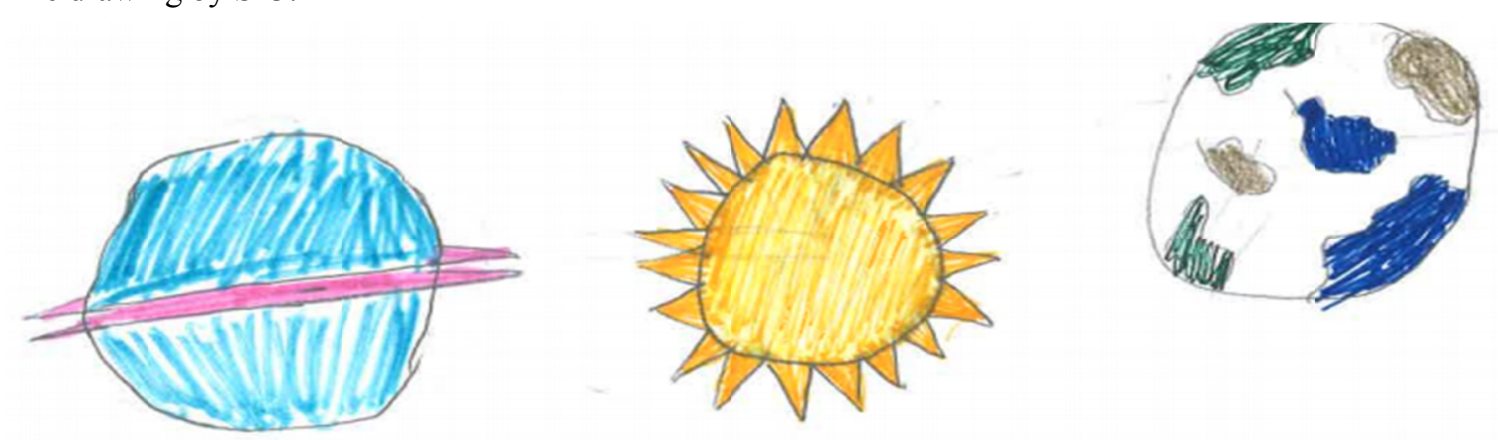
The drawing by S39:

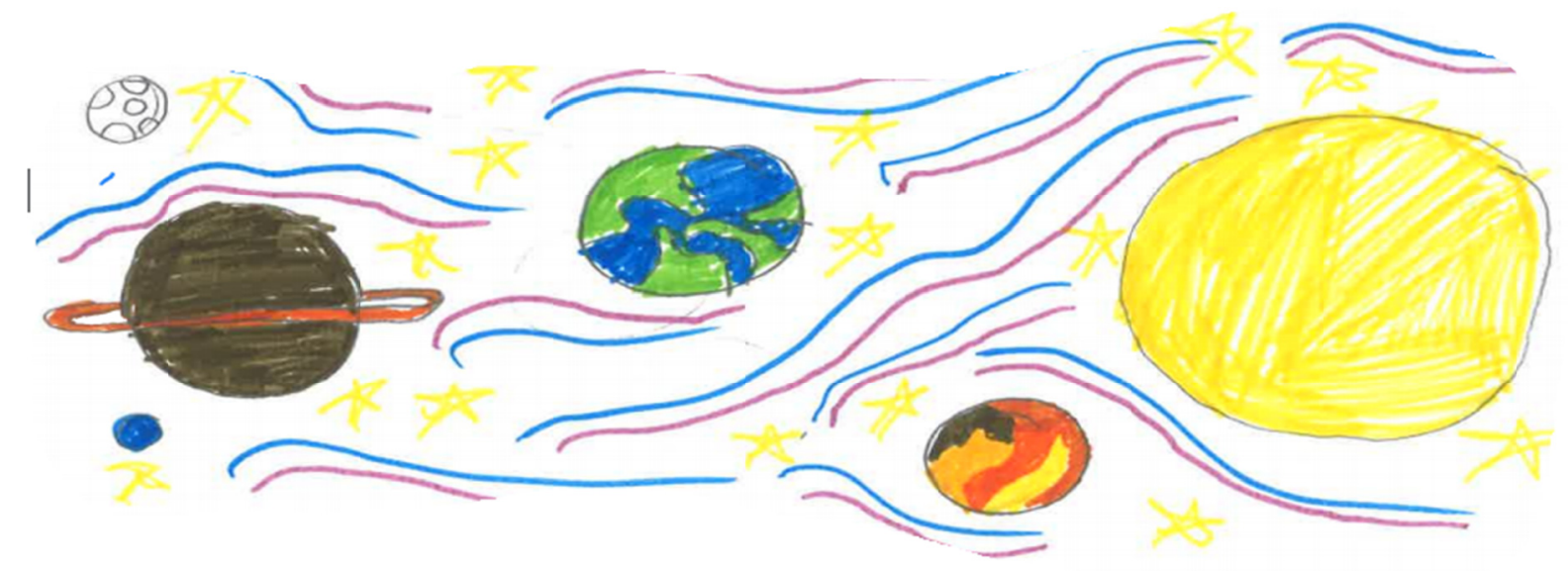

The findings revealed that 22 of the 144 students have the space exploration mental model. In the drawings included in this category, the students drew astronaut, spaceship and NASA. Sample drawings of the students for the space exploration model are presented below.

The drawing by S25:

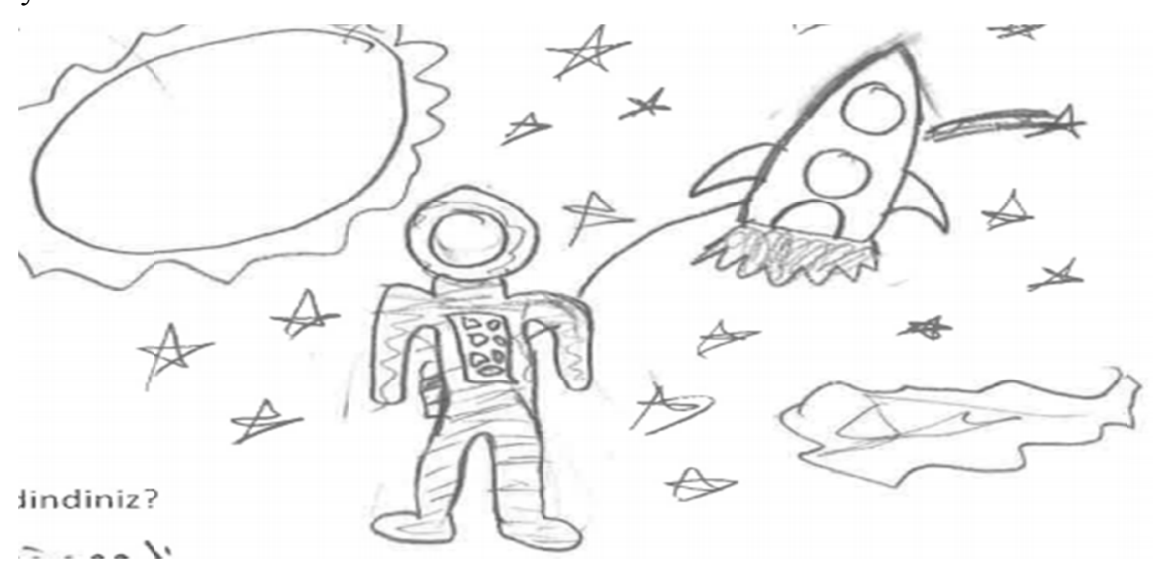

The drawing by S30:

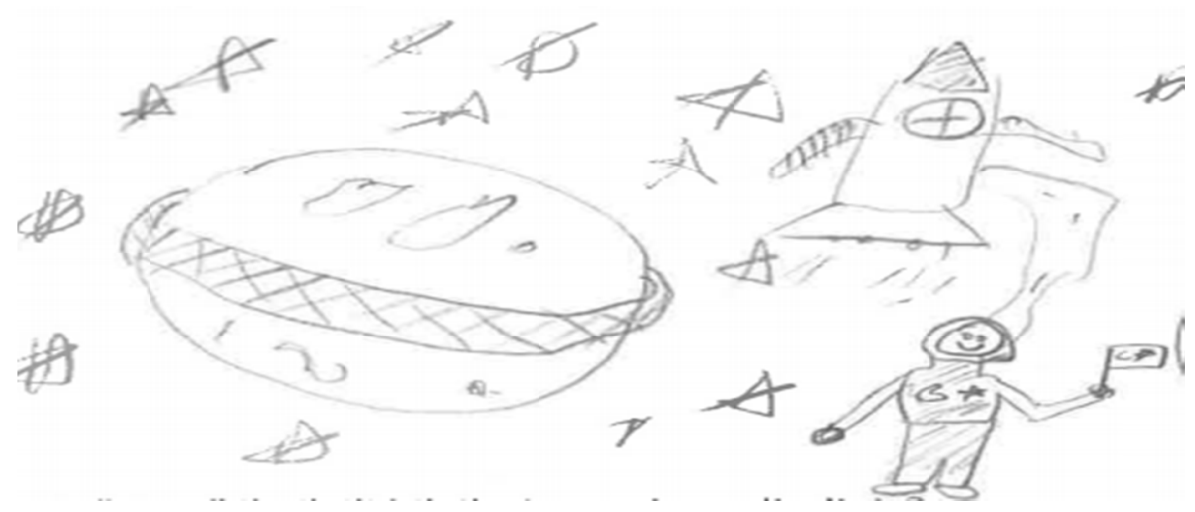


The drawing by S63:
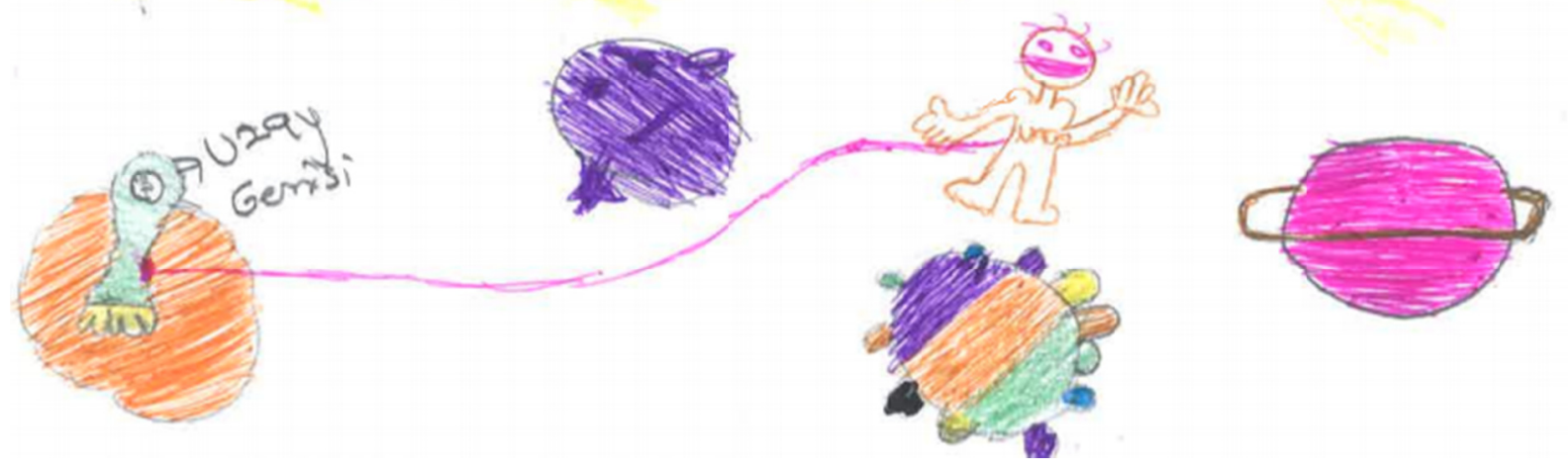

It was found that 22 of the 144 students have the solar system mental model. A sample drawing for the solar system mental model is given below.

The drawing by S34:

2. "Uzay” sözcüğünï-etuyduğunuzda zihninizde oluşan resmi çiziniz.

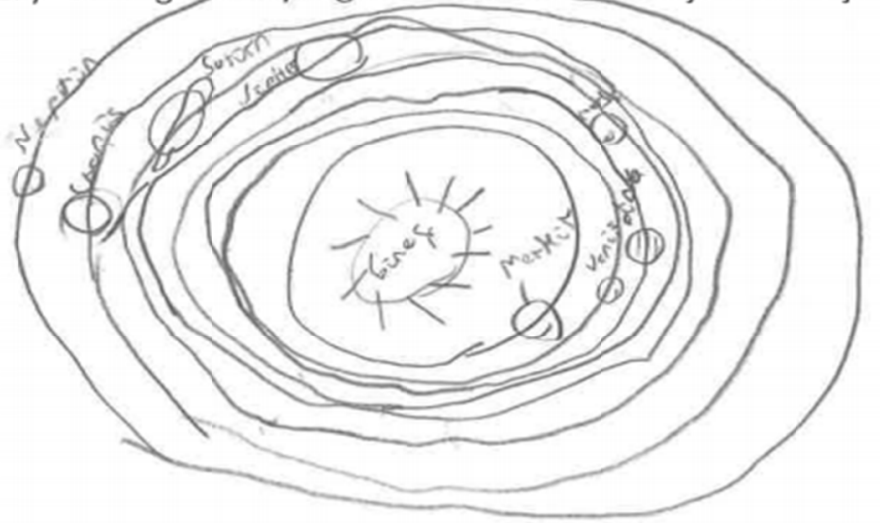

$$
\begin{aligned}
& \text { Nor= Buyuli güre gare } \\
& \text { yonmerishis? }
\end{aligned}
$$

It was found that 19 of the 144 students have the star mental model. In the students' drawings included in this category, it was detected that the students drew only star or stars within blueness. A sample for the star mental model is given below.

The drawing by S58:

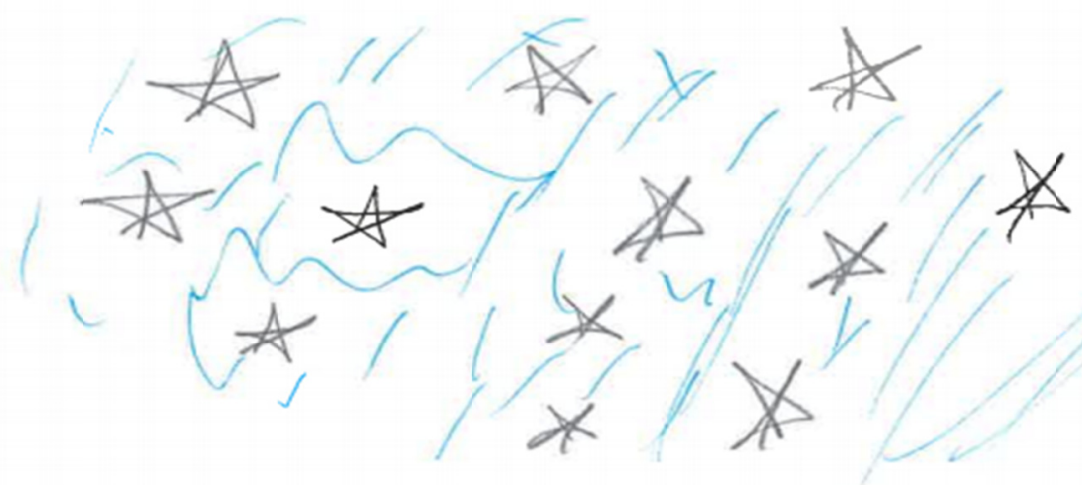


It was found that 9 of the 144 students have the alien mental model. A sample for the alien mental model is given below.

The drawing by S43:

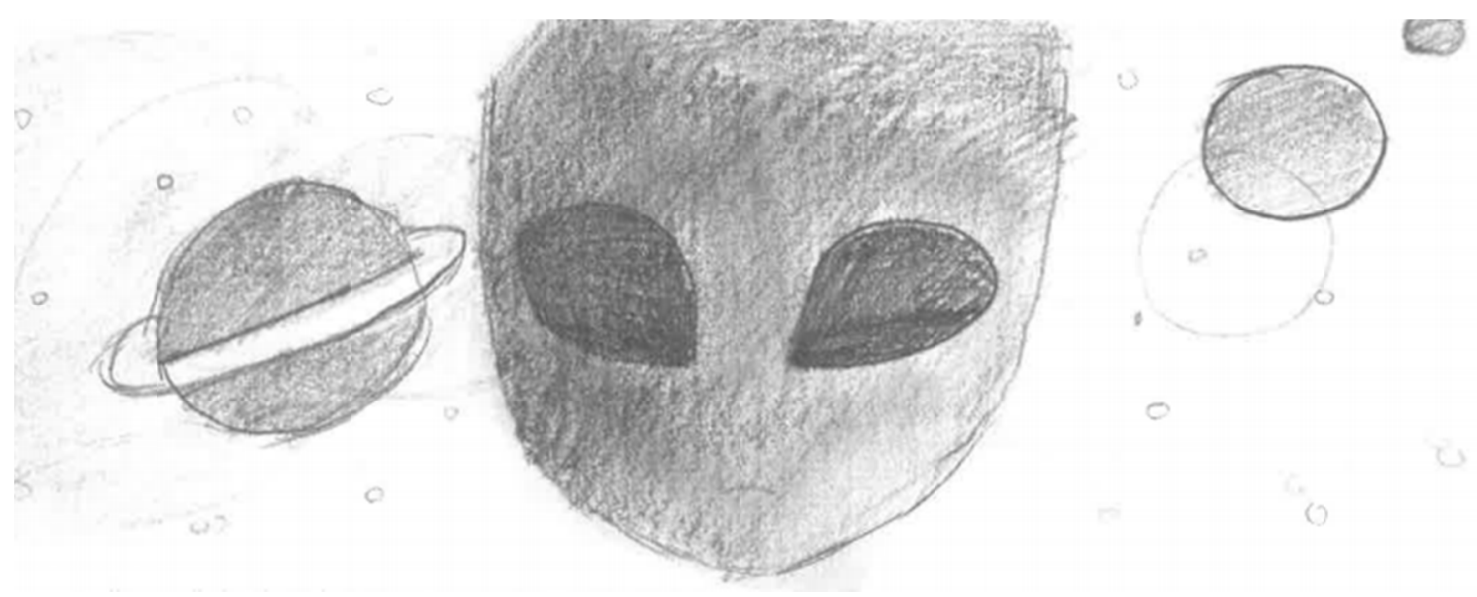

It was found that three of the 144 students have the darkness mental model. A sample for the darkness mental model is given below.

The drawing by S76:

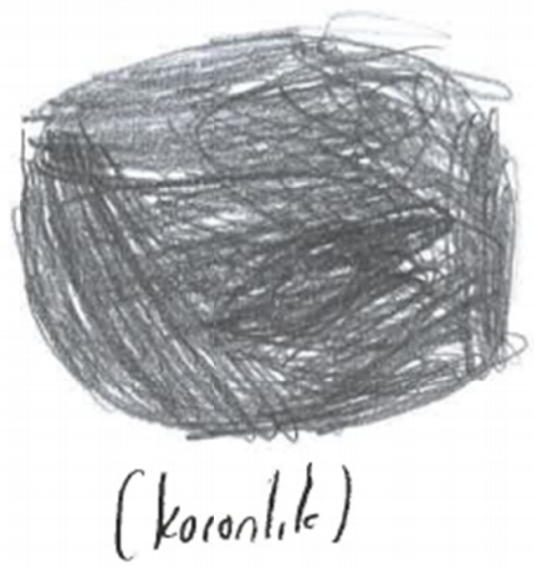

Findings obtained for the $3^{\text {rd }}$ question:

The findings obtained from the analysis of the secondary school students' responses to the question "Where have you received the information that you have about the "Space"?" are presented in Table 5. 
Table 5. The secondary school students' sources of information about space

\begin{tabular}{|c|c|c|c|c|c|c|c|c|c|c|}
\hline \multirow[b]{2}{*}{ Source } & \multicolumn{2}{|c|}{$1^{\text {st }}$ grade } & \multicolumn{2}{|c|}{$2^{\text {nd }}$ grade } & \multicolumn{2}{|c|}{$3^{\text {rd }}$ grade } & \multicolumn{2}{|c|}{$4^{\text {th }}$ grade } & \multicolumn{2}{|c|}{ Total } \\
\hline & $\mathrm{f}$ & $\%$ & $\mathrm{f}$ & $\%$ & $\mathrm{f}$ & $\%$ & $\mathrm{f}$ & $\%$ & $\mathrm{f}$ & $\%$ \\
\hline Internet & 24 & 57.14 & 19 & 50 & 11 & 35.48 & 20 & 60.60 & 74 & 51.38 \\
\hline School & 7 & 16.66 & 11 & 28.94 & 27 & 87.09 & 16 & 48.48 & 61 & 42.36 \\
\hline Reference book & 9 & 21.42 & 14 & 36.84 & 6 & 19.35 & 8 & 24.24 & 37 & 25.69 \\
\hline TV program & 11 & 26.19 & 8 & 21.05 & 1 & 3.22 & 5 & 15.15 & 25 & 17.36 \\
\hline Journal & 4 & 9.52 & 5 & 13.15 & 1 & 3.22 & 3 & 9.09 & 13 & 9.02 \\
\hline Mother & 7 & 16.66 & 4 & 10.52 & 1 & 3.22 & - & - & 12 & 8.33 \\
\hline Father & 6 & 14.28 & 4 & 10.52 & - & - & - & - & 10 & 6.94 \\
\hline Encyclopedia & 1 & 2.38 & 5 & 13.15 & 1 & 3.22 & 1 & 3.03 & 8 & 5.55 \\
\hline Friend & 1 & 2.38 & 5 & 13.15 & - & - & - & - & 6 & 4.16 \\
\hline Out-of-school (planet house) & 3 & 7.14 & 1 & 2.63 & - & - & - & - & 4 & 2.77 \\
\hline Sibling & 1 & 2.38 & - & - & 2 & 6.45 & - & - & 3 & 2.08 \\
\hline BILSEM (Science art education center) & 2 & 4.76 & - & - & - & - & - & - & 2 & 1.38 \\
\hline
\end{tabular}

When Table 5 is examined, it is seen that the first grade students have received their information about the space mostly from the internet and TV programs. In addition to these, mother, school, father and journals are important sources of information for the students. The number of students showing out-of-school environments as a source of information about the space is just 3. Moreover, only 1 student mentioned encyclopedia, sibling and friend each as the source of information. When Table 5 is examined, it is seen that the secondary school second grade students have received information about the space mostly from the internet, books and school. In addition to these, TV program, friend, encyclopedia and journal are other important sources of information about the space. The number of students showing the out-of-school environments as the source of information is 1. Only four students mentioned mother and father as the source of information. When Table 5 is examined, it is seen that the secondary school third grade students have received their information about the space mostly from the school. In the date, when the current study was conducted, the 2013 science curriculum was in effect and in this curriculum subjects related to the space are taught in the second term of the third grade within the unit "The Solar System and Beyond". While only 11 of the secondary school third graders have received their information about the space from the internet, 6 of the students have received this information from reference books apart from the course books. In addition to these, two students have received their information from encyclopedia and journal and three students from family members (mother, sibling). When Table 5 is examined, it is seen that the 4th grade students have received their information about the space mostly from the internet and school. In addition to these, other important sources of information for the students are reference book, TV program, encyclopedia and journal.

Findings obtained for the 4th question:

The findings obtained from the analysis of the students' responses to the question "Do you have any points that you wonder about in relation the "Space"? If yes, what are they? What would you like to learn about the "Space"?" are presented in Table 6 .

Table 6 . The findings obtained from the analysis of the students' responses to the question "Do you have any points that you wonder about in relation the "Space"? If yes, what are they? What would you like to learn about the "Space"?"

\begin{tabular}{|c|c|c|c|c|c|c|c|c|c|c|}
\hline \multirow{2}{*}{ Things the students are curious about } & \multicolumn{2}{|c|}{$1^{\text {st }}$ grade } & \multicolumn{2}{|c|}{$2^{\text {nd }}$ grade } & \multicolumn{2}{|c|}{$3^{\text {rd }}$ grade } & \multicolumn{2}{|c|}{$4^{\text {th }}$ grade } & \multicolumn{2}{|c|}{ Total } \\
\hline & $\mathrm{f}$ & $\%$ & $\mathrm{f}$ & $\%$ & $\mathrm{f}$ & $\%$ & $\mathrm{f}$ & $\%$ & $\mathrm{f}$ & $\%$ \\
\hline Is there life in the space? & 16 & 38.1 & 17 & 44.7 & 13 & 41.93 & 10 & 30.30 & 56 & 38.88 \\
\hline Planets & 4 & 9.5 & 8 & 21.1 & 5 & 16.12 & 3 & 9.09 & 20 & 13.88 \\
\hline Black holes & 7 & 16.7 & 2 & 5.3 & 3 & 9.67 & 5 & 15.15 & 17 & 11.80 \\
\hline Is the space infinite? & 1 & 2.4 & 1 & 2.6 & 4 & 12.90 & 7 & 21.21 & 13 & 9.02 \\
\hline Stars & 3 & 7.1 & 1 & 2.6 & 3 & 9.67 & 3 & 9.09 & 10 & 6.94 \\
\hline Galaxies & 1 & 2.4 & - & - & 2 & 6.45 & 4 & 12.12 & 7 & 4.86 \\
\hline Sun & 2 & 4.8 & 1 & 2.6 & 1 & 3.22 & - & - & 4 & 2.77 \\
\hline Space time concept & 1 & 2.4 & - & - & - & - & 2 & 6.06 & 3 & 2.08 \\
\hline Space vehicles & 1 & 2.4 & 1 & 2.6 & - & - & - & - & 2 & 1.38 \\
\hline Astronaut & 1 & 2.4 & - & - & - & - & - & - & 1 & 0.69 \\
\hline Color of the space & - & - & - & - & 1 & 3.22 & - & - & 1 & 0.69 \\
\hline None & 5 & 11.9 & 7 & 18.4 & 4 & 12.90 & 5 & 15.15 & 21 & 14.58 \\
\hline
\end{tabular}


When Table 6 is examined, it is seen that 21 of the 144 students do not have anything they wonder about in relation to the space. Of these 21 students, 5 are first graders, 7 are second graders, 4 are third graders and 5 are fourth graders. When Table 6 is examined, it is seen that 123 students have some points they wonder about in relation to the space and these points are grouped under various headings. It is seen from Table 6 that the most wondered point by the students is whether there is life in the space and they want to learn the answer to this question. In this category, there are 56 students. Some sample student responses are given below.

S12: “There are some points I wonder about. Are there living things in the space? If there are, what are they? "(IS THERE LIFE IN THE SPACE)

S27: "Is there life in the space? Where will people go on living when the world is destroyed? Is it possible to plant a tree in the space?" (IS THERE LIFE IN THE SPACE)

As can be seen in Table 6, 20 students wonder about planets and issues related to the structure of planets. Some sample student responses in this category are given below.

S10: "Yes, there is. I wonder how planets came into being." (PLANET)

S22: "The surface of planets and living things in spaces." (PLANET)

S96: "I wonder about everything regarding the space. I want to learn detailed information about Jupiter and Saturn." (PLANET)

As can be seen in Table 6, the third place among the subjects most wondered about in relation to the space is taken by black holes. Of the 144 students, 17 wonder about black holes and 7 of these 17 students are first graders, 2 are second graders, 3 are third graders and 5 students are fourth graders. Some sample students responses in this category are given below.

S6: "What is there inside the black hole?" (BLACK HOLES)

S26: "How did black holes occur?" (BLACK HOLES)

As can be seen in Table 6, another issue wondered about by students is whether the space is infinite or not. There are 13 students in this category and 7 of them are fourth graders, 4 are third graders, 1 is a second grader and 1 is a first grader. One student sample response in this category is given below.

S112: "I would like to learn whether the space is infinite or not." (IS THE SPACE INFINITE)

The structure of planets, galaxies, space-time concept, space vehicles, astronaut and color of the space are among the issues wondered about by fewer students. Some sample student responses in these categories are given below.

S7: "I wonder how big stars are." (STAR)

S16: "I wonder how many galaxies there are in the space and how many of them have been observed." (GALAXY)

S48: "Does the sun explode? And why do not we hear the sound of solar flares?" (SUN)

S19: "There are many things I wonder about in relation to the space. I wonder why the person travelling to the space feels as if it was a very short time but when the same person comes back to the earth, he/she realizes many years have passed." (SPACE TIME CONCEPT)

S31: "I wonder how rockets stay in the space for a long time." (SPACE VEHICLES)

S37: "How is the life of astronauts? Do they feel any discomfort before going to the space?" (ASTRONAUT)

S117: "Is the space same as I see from the internet or is it in the colors of dark blue, white and magenta?" (COLOR OF THE SPACE)

\section{Discussion and Conclusion}

The current study was conducted to elicit the mental models of the students from different grade levels about the concept of space. At the same time, the study aimed to determine the factors playing a role in the construction of their concepts of space. The findings of the study revealed that the students associated the concept of space mostly with the concepts of emptiness ( 53 students), infinity ( 50 students), planet (48 students) and star (28 students). This finding is supported with the data derived from the students' drawings and the celestial bodies mental model was used by 69 students. This finding concurs with the findings reported by similar studies in the literature. Celik \& Tekbiylk (2016) also concluded that the students associate the concept of space with celestial bodies.

When the students' drawings of the space were examined, 6 different mental models were detected and the most commonly adopted model was found to be the celestial bodies mental model (69 students). In this model, the students drew the space as consisting of celestial bodies. Moreover, in almost all of the drawings in this category, 
sun, world and moon were included. The analysis of the students' drawings revealed that 22 students have the space exploration mental model and 22 students have the solar system mental model. The students exposed to the sun-centered system many times may have internalized this model in their minds.

The less frequently adopted models by the students are the star model (19 students), the alien model ( 9 students) and the darkness model ( 3 students). Celik \& Tekbiylk (2016) found that the celestial bodies model had been used by many of the students. Description of the space as a dark place also concurs with the findings of Karamustafaoglu \& Akturk (2016). Moreover, when the students' drawings were examined, it was seen that the students drew the stars with five corners. Similar findings have also been reported by different studies in the literature (Iyibil, 2010; Iyibil \& Saglam-Arslan, 2010; Kurnaz, 2012; Arıkurt, 2015). This might be interpreted as students' having been affected by their observations in their daily lives or cultural values (star with five corners in flags). The current study also determined the students' sources of information about the space and except for the third graders; the internet took the first place as a source of information for the other graders. In general, while the internet took the first place among the sources of information about the space, it is followed by the school, books other than course books and TV programs. In addition to these, journals, mother, father, encyclopedia, friends, out-of-school activities (planet house), siblings and BILSEM are other sources of information for the students. When the 2013 science curriculum is examined, it is seen that students in the first grade can learn information about the issues related to the earth crust, erosion and environmental pollution, students in the second grade can learn information about the world, the sun and the moon, students in the third grade can learn about many celestial bodies such as stars, planets, meteors, satellites, comets and star clusters within the unit "The Solar System and Beyond". When students become the fourth graders in the secondary education, they receive information about issues such as earthquakes, seasons, weather events and plate motions. In the current study, the secondary school third graders stated that the school takes the first place among their sources of information about the space. This seems to be natural as the science curriculum informs students about the space, the structure of the space, and research on the space in the third grade of the secondary education. According to Cin (2007), on the basis of students' some alternative ideas about the basic concepts of astronomy lay course books and reference books. Celik and Tekbiyık (2016) concluded that TV programs, story books and course books are influential on the formation of mental models of the concept of space. According to The European Association for Astronomy Education (EAAE) (1994), astronomy teaching should be initiated as early as possible in the elementary education because students might receive some erroneous information from TV programs or other broadcasting organizations.

Fletcher (1980), Mallon \& Bruce (1982), and Sontay, Tutar, \& Karamustafaoglu (2016) have found that planetarium has an important place in astronomy education and student achievement. Fletcher (1980) stated that subjects that are difficult to comprehend and visualize by students can be taught by using extracurricular learning environments such as planetarium or observatory, and that students can comprehend the subjects to be taught in these environments more effectively and in a shorter time. Yet, within the context of the current study, only the 4th graders mentioned that they gained information about the space in out-of-school environments. The current study also aimed to determine the points wondered about by the students in relation to the concept of space and it was found that 21 of the 144 students do not have anything they wonder about in relation to the space. On the other hand, 123 students were found to have some points they wonder about and these points are grouped under different headings. One of the interesting points in this regard is that 56 of the participating students wonder whether there is life in the space or not. In addition, the students wonder about the structure of planets, the structure of black holes and how many of them there are, the structure of galaxies and whether the space is infinite or not. The issues least wondered about by the students are the sun, time-space concept, space vehicles, astronauts and the color of the space.

In a study conducted by TUBITAK in order to measure the scientific literacy of 15-24 year-olds in Turkey, it was determined that "Internet" and "Astronomy" were the subjects that attracted the most attention of the individuals. Considering that the cognitive structures of the students have started to form at early ages, it is necessary to expand the studies especially covering the primary and secondary school periods. The misconceptions of the students in this age period need to be elicited and eliminated. At this point, especially the qualities of the classroom teachers, social sciences teachers and science teachers who give the first information about astronomy subjects should be enhanced thus the formation of alternative concepts in students' minds can be avoided. Moreover, future research may look at the effect of students' demographic features on their mental models of space. Given that the internet, school, references books and TV programs are the most influential sources on the development of students' mental models of the space, it can be suggested that up-to-date visual models should be used in these sources. In a similar manner, in science-fiction movies and animations, it needs to be emphasized that the space is not a dark and 
frightening place. Moreover, out-of-school environments where students can have more experiences about the space and their learning can be more permanent should be utilized more within the context of science course.

\section{References}

Arıkurt, A., Durukan U. G., \& Sahin, C. (2015). Farklı ogrenim seviyesindeki ogrencilerin astronomi kavramıla ilgili goruslerinin gelisimsel olarak incelenmesi. Amasya Universitesi Egitim Fakultesi Dergisi, 4(1), 66-91.

Atasoy, B. (2004). Fen Ogrenimi ve Ogretimi (2. Baskı). Ankara: Asil Yayın.

Ayvacı, H. S., Bebek, G., Atik, A., Keles, C. B., \& Ozdemir, N. (2016) Ogrencilerin sahip olduklari zihinsel modellerin modelleme sureci icerisinde incelenmesi: hucre konusu ornegi. Dicle Universitesi Ziya Gokalp Egitim Fakultesi Dergisi, 28, 175-188. https://doi.org/10.14582/DUZGEF.711

Bektasl1, B. (2013). The effect of media on preservice science teachers' attitudes toward astronomy and a chievement in astronomy class. The Turkish Online Journal of Educational Technology, 12(1), 139-146.

Boulter, C. J., \& Buckley, B. C. (2000). Constructing a typology of models for science education. In J. K. Gilbert \& C. J. Boulter (Eds.), Developing models in science education (pp. 41-57). Dordrecht: Kluwer Academic Publishers.

Bulbul, E., Iyibil, U. G., \& Sahin, C. (2013). Ortaokul 8.sınıf ogrencilerinin astronomi kavramıyla ilgili algılamalarının belirlenmesi. Egitim ve Ogretim Araştırmaları Dergisi, 2(3), 182-191.

Celik, M., \& Tekbıyık, A. (2016). Ilkokul ikinci sinıf ogrencilerinin dunya ve uzay kavramlarina yonelik zihinsel modelleri ve imajlari. International Journal of Eurasia Social Sciences, 7-25, 271-289.

Cepni, S. (2010). Araştırma ve Proje Calışmalarına Giriş (5th ed.). Trabzon: Celepler Matbaacılık.

Chia-yu, W. (2007). The role of mental-modeling ability, content knowledge, and mental models in general chemistry students' understanding about molecular polarity. Dissertation of Phi losophy, the Faculty of the Graduate School University of Missouri, Columbia.

Cin, M. (2007). Alternative views of the solar systems among Turkish students. International Review of Education, 53(1), 39-53. https://doi.org/10.1007/s11159-006-9029-5

Coll, R. K., \& Treagust, D. F. (2003). Investigation of secondary school, undergraduate and graduate learners' mental models of ionic bonding. Journal of Research in Science Teaching, 40(5), 464-486. https://doi.org/10.1002/tea.10085

De Posada, J. M. (1997). Conceptions of high school students concerning the internal structure of metals and their electric conduction: Structure and Evolution. Science Education, 81(4), 445-467. https://doi.org/10.1002/(SICI)1098-237X(199707)81:4<445::AID-SCE5>3.0.CO;2-C

Fletcher, J. K. (1980). Traditional planetarium programming versus participatory planetarium programming. School Science and Mathematics, 80(3), 227-232.

Franco, C., \& Colinvaux, D. (2012). Grasping mental models. In J. K. Gilbert \& C. J. Boulter (Eds.), Developing models in science education (ss. 93-118). New York, NY: Springer Netherlands. https://doi.org/10.1007/978-94-010-0876-1

Gorecek Baybars, M. (2017). Fen bilgisi ogretmen adaylarının metallerin elektrik iletkenligi ile ilgili zihinsel modelleri. ICEMST 2017: International Conference on Education in Mathematics, Science \& Technology. Ephesus Kusadasi, Turkey, May, 18-21, 2017.

Hestenes, D. (2006). Notes for a modeling theory of science, cognition and instruction. Proceedings of the 2006 GIREP Conference: Modelling in Physics and Physics Education. Amsterdam, Netherlands.

International Astronomical Union. (2012) IAU Astronomy for Development Strategic Plan 2010-2012. Erişim: 04.05.2016. Retrieved from http://www.iau.org/static/education/strategicplan_2010-2020.pdf

Iyibil, U. \& Saglam Arslan, A. (2010). Fizik ogretmen adaylarının yıldız kavramına dair zihinsel modelleri, Necatibey Egitim Fakultesi Dergisi, 4(2), 25-46.

Iyibil, U. G. (2010). Farklı programlarda ogrenim goren ogretmen adaylarının temel astronomi kavramlarını anlama duzeylerinin ve ilgili kavramlara ait zihinsel modellerinin analizi. Yuksek Lisans Tezi, Karadeniz Teknik Universitesi, Fen Bilimleri Enstitusu. Trabzon.

Jabot, M., \& Henry, D. (2007). Mental models of elementary and middle school students in analyzing simple battery and bulb circuits. School Science and Mathematics, 107, 371-381. 
Joolingen, W., Aukes, A., Gijlers, H., \& Bollen, L. (2015). Understanding Elementary Astronomy by Making Drawing-Based Models. Journal of Science Education \& Technology, 24-2/3, 256-264. https://doi.org/10.1007/s10956-014-9540-6

Karamustafaoglu, S., \& Akturk, M. (2016). İlkokul ogrencilerinin “uzay” kavramına ilişkin metaforları. Turkish Studies -International Periodical for the Languages, Literature and History of Turkish or Turkic-, 11/3, $1387-1406$.

Kibble, B. (1999). How do you picture electricity?. Physics Education, 34(4), 226-229. https://doi.org/10.1088/0031-9120/34/4/310

Kurnaz, M. A. (2012). Yıldız, kuyruklu yıldız ve takımyıldız kavramlarıyla ilgili ogrenci algılamalarının belirlenmesi. Abant Izzet Baysal Universitesi Egitim Fakultesi Dergisi, 12(1), 251-264.

Kurnaz, M. A., \& Degermenci, A. (2012). 7. Sınıf ogrencilerinin guneş, dunya ve ay ile ilgili zihinsel modelleri. IlkOgretim Online, 11(1), 137-150.

Liu, S. H. (2003). Models of "The Heavens and the Earth": An investigation of German and Taiwanese students' alternative conceptions of the universe. International Journal of Science and Mathematics Education, 3, 295-325. https://doi.org/10.1007/s10763-004-4032-4

Mallon, G. L., \& Bruce, M. H. (1982). Student achievement and attitudes in astronomy: An experimentalmcomparison of two planetarium programs. Journal of Research in Science Teaching, 19(1), 53-61.

Ornek, F. (2008). Models in science education: applications of models in learning and teaching science, International Journal of Environmental \& Science Education, 3(2), 35-45.

Ozturk, D. (2011). İlkogretim 6. ve 8. sınıf ogrencilerinin ayın evreleri konusunda kavram yanılgıları ve kavram degişimlerinin işbirligine dayalı ortamda incelenmesi. Yuksek Lisans Tezi, Cukurova Universitesi. Adana.

Panagiotaki, G., Nobes, G., \& Potton, A. (2009). Mental models and other misconceptions in children's understanding of the Earth. Journal of Experimental Child Psychology, 104(1), 52-67. https://doi.org/10.1016/j.jecp.2008.10.003

Patton, M. Q. (2014). Nitel araştırma ve degerlendirme yontemleri. 3. Baskıdan Ceviri. In M. Butun \& S. B. Demir (Eds.). Ankara: Pegem Akademi.

Rapp, D. (2005). Mental models: Theoretical issues for visualizations in science education. In J. K. Gilbert (Ed.), Visualization in Science Education, 43-60. Netherlands.

Samarapungavan, A., Vosniadou, S., \& Brewer, W. F. (1996). Mental models of the Earth, Sun, and Moon: Indian children's cosmologies. Cognitive Development, 11, 491-521.

Sontay, G., Tutar M., \& Karamustafaoglu, O. (2016). Okul dışı ogrenme ortamları ile fen ogretimi” hakkında ogrenci goruşleri: Planetaryum gezisi. Informal Ortamlarda Araştırmalar Dergisi, 1(1), 1-24.

Spiliotopoulou-Papantoniou, V. (2007). Models of the universe: Children's experiences and evidence from the history of science. Science and Education, 16, 801-833. https://doi.org/10.1007/s11191-006-9034-x

Straatemeier, M., Van der Mass, H. L. J., \& Jansen, B. R. J. (2008). Children's knowledge of the Earth: A new methodological and statistical Psychology. Journal of Experimental Child, 100, 276-296.

Taylor, I., Baker, M., \& Jones, A. (2003). Promoting mental model building in astronomy education, International Journal of Science Education, 25(10), 1205-1225. https://doi.org/10.1080/0950069022000017270a

Trumper, R. (2006). Teaching future teachers basic astronomy conceptsseasonal changes-at a time of reform in science education. Journal of Research in Science Teaching, 43(9), 879-906. https://doi.org/10.1002/tea.20138

Tunca, Z. (2002). Turkiye'de ilk ve orta ogretimde astronomi egitim ogretiminin dunu, bugunu. V. Ulusal Fen Bilimleri ve Matematik Egitimi Kongresi, Ankara, Eylul 2002.

Turk, C. (2010). Ilkogretim temel astronomi kavramlarının ogretimi. Yayınlanmamış Yuksek Lisans Tezi, Ondokuz Mayls Universitesi. Samsun.

Turk, C., Alemdar, M., \& Kalkan, H. (2012). Ilkogretim ogrencilerinin mevsimler konusunu kavrama duzeylerinin saptanmas1. Journal of Educational and Instructional Studies in the World, 2(1), 2146-7463. 
Ucar, S., \& Demircioglu, T. (2011). Changes in preservice teacher attitudes toward astronomy within a semester long astronomy instruction and four year-long teacher training program. Journal of Science Education and Technology, 20, 65-73.

Unal, G. \& Ergin, O. (2006). Fen egitimi ve modeller. Milli Egitim Dergisi, 171, 188-196.

Unat, Y. (2010). Osmanlılarda bilim ve teknoloji (Editor). Nobel Yayınevi, Ankara.

Vosniadou, S. (1994). Capturing and modelling the process of conceptual change. Learning and Instruction, 4(1), 45-69.

Vosniadou, S. (2002). On the nature of naive physics. In M. Limon \& L. Mason (Eds.), Reconsidering conceptual change: Issues in theory and practice (pp. 61-76). New York: Kluwer Academic Publisher.

Vosniadou, S., \& Brewer, W. F. (1992). Mental models of the earth: A study of conceptual change in childhood. Cognitive Psychology, 24(4), 535-585.

Vosniadou, S., Skopeliti, I., \& Ikospentaki, K. (2004). Modes of knowing and ways of reasoning in elementary astronomy. Cognitive Development, 19, 203-222.

White, R. T., \& Gunstone, R. F. (1992). Probing understanding. New York: The Falmer Press.

Williamson, V. M., \& Abraham, M. R. (1995). The effects of computer animation on the particulate mental models of college chemistry students. Journal of Research in Science Teaching, 32, 521-534. https://doi.org/10.1002/tea.3660320508

Wittman, D. (2009). Shaping attitudes toward science in an introductory astronomy class. The Physics Teacher, 47, 591-594. https://doi.org/10.1119/1.3264591

Wood, D. J. (2005). How children think and learn: The social context of cognitive development (2nd ed.). Oxford: Blackwell.

Yin, R. K. (2003). Case study research: Design and Methods (3rd ed.). London.

Yurumezoglu, K., \& Cokelez, A. (2010). Akım geciren basit bir elektrik devresinde neler oldugu konusunda ogrenci goruşleri. Turk Fen Egitimi Dergisi, 7(3), 147-166.

\section{Copyrights}

Copyright for this article is retained by the author(s), with first publication rights granted to the journal.

This is an open-access article distributed under the terms and conditions of the Creative Commons Attribution license (Ohttp://creativecommons.org/licenses/by/4.0/). 